\title{
The new media strategy of the Serbian Armed Forces as an instrument of soft power
}

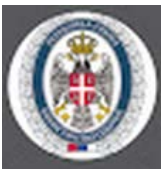

Received: $17 / 09 / 2021$

Revised: 30/09/2021

Accepted: 05/10/2021

Published: 06/12/2021

Corresponding author:

Nenad Perić

Correspondence email:

nesaperic@hotmail.com

DOI:

10.5937/vojdelo2103060P

\begin{tabular}{|l|l|l|l|l|l}
\hline c & e & o & n \\
\hline c & e & e & s \\
\hline
\end{tabular}

\begin{tabular}{l|l|l|l|l|l}
\hline c & e & e & s \\
\hline
\end{tabular}

\author{
Nenad Perić, Miroslav Mitrović ${ }^{2}$ \\ 'Univerzitet Union - Nikola Tesla, Fakultet za diplomatiju i bezbednost, Beograd \\ ${ }^{2}$ Univerzitet odbrane u Beogradu, Institut za strategijska istraživanja
}

\begin{abstract}
:
The paper elaborates the concept and significance of media policy and implements it to the Serbian Armed Forces. The importance of the media in the security sector at national and international level is analyzed and the need for good media representation of the Serbian Armed Forces is emphasized in order to support the public for important decisions concerning military and security issues. The concept of strategic communications and their relationship with the media policy that the Armed Forces should develop as one of the instruments of soft power, which is of interest not only to this system, but also to the state and society, has been presented. Moreover, the main elements are presented, whose fulfillment would create conditions for the establishment and conduct of an adequate media policy as an instrument of soft power.
\end{abstract}

Keywords: Serbian Armed Forces; media policy; media; strategic communications; public; public opinion

\section{INTRODUCTION}

The new age brings a new reality: "... the development of technology and information revolution have established a completely new environment, both for political decision-makers on military actions and for the very Armed Forces" [1]. It is becoming increasingly clear that geostrategic goals (primarily of great powers) are achieved through the following line of pressure: political and diplomatic, economic, media and military. However, the military one is usually used in the end. Before that, the other mentioned pressures are combined, which may have pronounced intelligence-informative or mediacommunication elements/strategies [3][4]. The latter aim to gain their own public, groups, informal and formal centres of power, as well as foreigners, who are relevant in a given situation [2].

The most well-known experts in the field of PR focused on military-political issues [5][6][7][8] agree that the influence of public opinion can be of great importance for making and implementing decisions related to military and security issues. This does not mean decisions on entering into acts of war, but the relationship and interdependence of the state (state leadership) and the military, the people and the military, redesigning the role of the military, its transformation, etc. "Important decisions in the field of politics, finance, security and other elites can be made without the public support, but the chances for their long-term and successful implementation are then significantly reduced" [2].

The security reform and defence policy-making has to take into account the fact that security and defence are increasingly becoming political issues, which would have to be understood to the general public in order to support them [9]. One of the main problems in this process is the one that affects the entire public sector of Serbia, including the military system. It is the problem of insufficiently developed communication that has only recently been given more importance, which is largely caused by unorganized (or insufficiently implemented) legislation and insufficiently built awareness in the society and institutions about the importance of high-quality, timely and organized communication. 


\section{STRATEGIC COMMUNICATION, MEDIA AND SOFT POWER - THE NEED TO DEVELOP THE MEDIA STRATEGY OF THE SERBIAN ARMED FORCES}

Strategic communication is a term used to denote the highest level of engagement of communication achievements of an organization in improving its mission [10]. In the context of national defence and security, strategic communication can be identified with each activity, statement, message, description and action of the state armed forces that affects the perception and public opinion of the population that witnesses it [11]. Strategic communications management implies the way in which an organization presents itself in the society as a social actor in creating public culture and considering issues of public importance. In this sense, strategic communication can be considered through:

- national (state) institutional level, which includes: public diplomacy, psychological operations, social marketing, propaganda and interest communications (lobbying, advocacy, strategic negotiation);

- corporate level, which includes: public relations, integrated marketing communications, socially responsible practice, corporate political activities [12].

Strategic security communication plays a significant role in national and international relations, and should stem from strategic national interests. It can be viewed as a process, goal or means of achieving interest.

In this sense, the main object of strategic communication is the public in all its segments, and the instruments and channels of action are the media-traditional (TV, radio, press) and modern (Internet and new media).

The impact on public opinion is achieved through campaigns, which, in principle, contain three main phases [13]:

- defining issues in the public through the use of activist groups and their actions, involving opinion leaders, who divert the public's focus on the desired topic. At this stage, the public, which is wider than driving group, becomes aware of a problem. With the increase of interest, the popularization of a problem grows with the constant presence of the media;

- the involvement of the media, which, in order to more clearly convey a message and encourage a wider audience, simplify the interpretation of a problem, thus making it easier for new, previously disinterested individuals to participate in discussing a problem and taking a stance;

- the involvement of the state institutions. The popularization of a problem leads to an increase in the motivation of stakeholders and the involvement of the institutions of the state, which is under pressure to take steps to resolve an issue. The pressure is exerted from the public base ("the public wants") while at the same time using the really aroused interest ("the public needs"). The whole process is completely covered with the assistance of the media, which practically maintain the required level of tension and the presence of a topic in the phased conquest of a wider circle of the public.

From the point of view of correlations and conditioning of the public, media and politics in the context of the security sector, contemporary literature identifies the processes of influencing political decisions from influencing security and foreign policy. These influences are carried out in the cycle "politics - media - politics", within which the holders (communicators), processes (media reporting, political processes), ambience (topic coverage, political ambience) with the strong influence of information controllers (gatekeeping) are emphasized, all within the set paradigm of strategic communication goals [14] (Figure 1). 


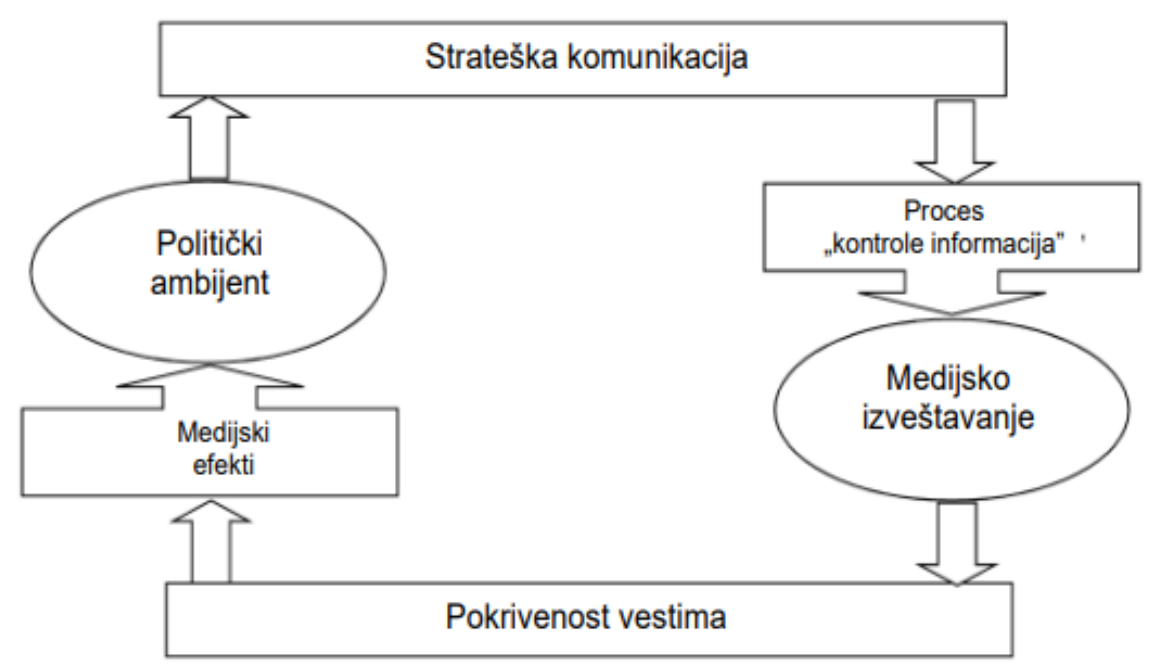

Figure 1.

Model of cyclical influence of politics - media - public [15]

There is no doubt that the media have a strong stimulating effect on creating people's opinions, more precisely, on creating public opinion. Furthermore, the media are an instrument of strategic communication, which is one of the expressions of the state power and an instrument in political and security fulfillment of national interests. Strategic communication is an expression of the state soft power and its systems (the Armed Forces is one of the most important systems in the case of the Republic of Serbia) and can have an offensive and defensive character. The conditionality of strategic communication as the subject of preservation and protection of national values and interests, and thus elements of national security, establishes the need for resilience and informative vitality of a nation. This further causes the need to develop an adequate media strategy at national level. The Serbian Armed Forces are the main holder of the defence function, so it is natural and necessary for them in the conditions of the importance of strategic communication for the execution of their mission to begin the development of a current media strategy relevant for modern conditions.

\section{MEDIA POLICY}

Media policy is a continuous media action on certain demographic groups. It consists of determining general and communication goals, their execution - through media campaigns and public relations, and through selected communication channels - the media [2].

Media policy is a means of addressing a wide audience, the society, at national and international level in continuity. The unification of communication instruments is necessary in order to derive a good rating from coordinated and harmonious actiona positive image and the better and longer-lasting relationship with different target groups. The establishment of media policy and public opinion is influenced by many elements which, depending on their strength and representation, influence the communication process. Among them are: a type of the society (various demographic, sociological, educational, cultural, religious and developmental factors), historical circumstances and experiences, media development of the state, surroundings, general circumstances, etc [2] (Figure 2). 


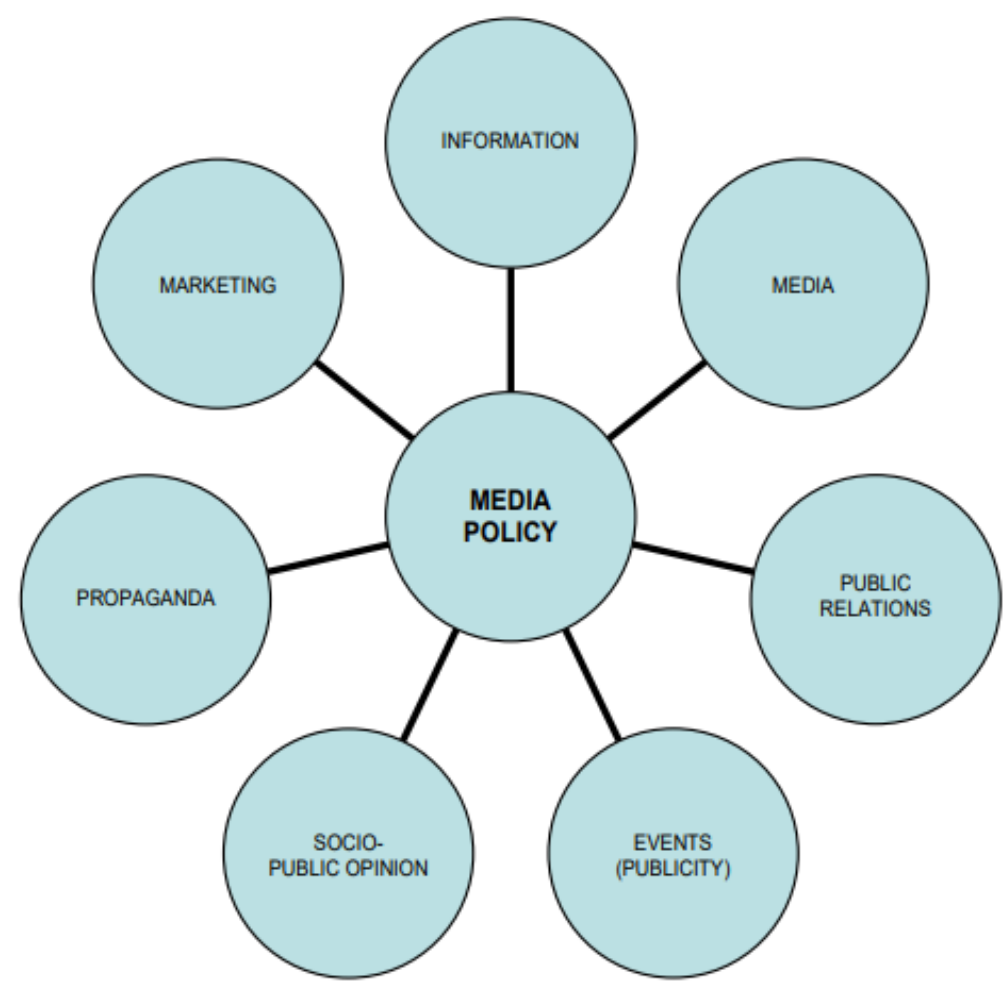

Figure 2.

„Wheel” of media policy

However, media policy, in addition to its moment of mass address, has a tendency of exceptional segmentation of the audience when the address/action conditioned (or marked) by complex or socially rather important issues is ,"produced”. This is done for two main reasons. The first is based on easier selection of communication strategies, means and messages in relation to individual groups, in order to increase the efficiency of media activities. The focus is on the creator and recipient of a message with its anthropological (cultural, social and psychological) characteristics, then communication strategy and argumentation contained in a message, and linguistic factors [2].

The second reason lies in deeper social segmentation. There are two types of opinion leaders (public opinion) - formal and informal [16]. The former have been given this name because they represent elected officials (institutional, political, non-governmental, high-ranking organizational or corporate and public persons). Journalists often ask them for statements, that is, opinion on a specific issue concerning their responsibilities or interests. These are "legitimate, formal leaders of power".

The second group consists of informal opinion leaders, those who have an impact on people, groups and their environment due to their personal characteristics, such as: information, knowledge - credibility, articulation, leadership and charisma, driving force. The deeper segmentation of media activities and media policy tries to identify this part of the society. According to many sociologists, and their research, the importance of these leaders is enormous, often crucial. The result of that research is the theory of two-phase communication, which later grew into the theory of multiphase flow, although it is basically the same idea: public opinion is formed by the opinions of people who have already refined information, evaluated them and formed an opinion that is transferred to others. This model is presented as a series of concentric circles, whose epicentre contains opinion makers. They receive great quantities of information through mass media and other sources, and forward some of that information to the next circle, whose members represent the interested public. By expanding the circles, 
we come to the disinterested public that remains out of the process of public opinion, although a part of the people from this circle will still get some information and show interest [2].

\section{MEDIA POLICY OF THE SERBIAN ARMED FORCES}

The majority of the most important practitioners and media theorists believe that wider masses (i.e. those who ultimately form the basis of public opinion) are usually neither sufficiently (well) informed, nor educationally and culturally mature to draw their own conclusions... they do it with assistance $[17][18][19][20][21][22][23][24]$. These relationships are shown in Figure 3.

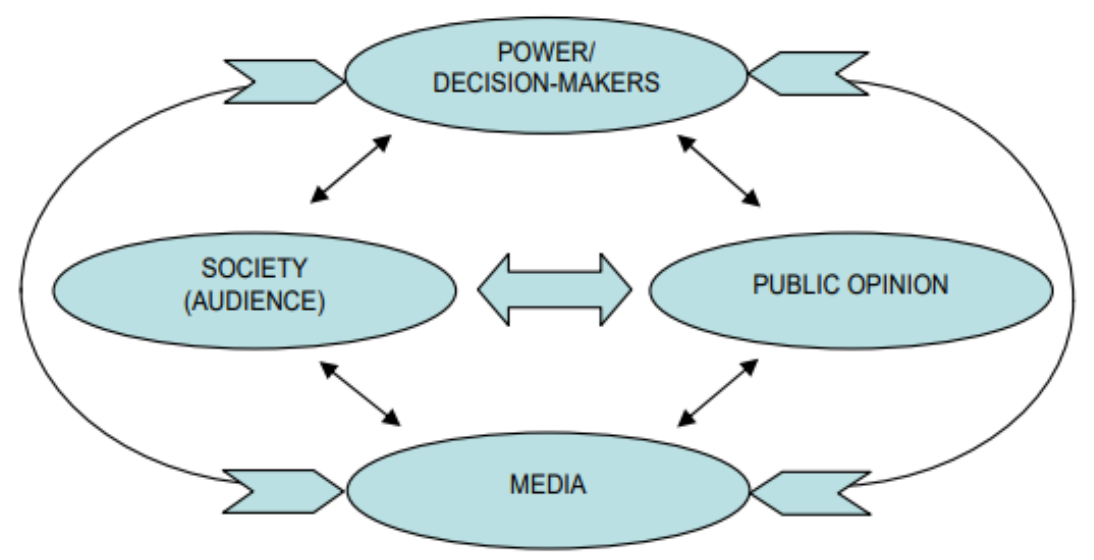

Figure 3.

Elements and process of political and security decision-making [2]

In their assessments of security and defence, people usually depend on external information and interpretations: addresses and speeches of their political leaders, statements of their government and other institutions, information and comments on television, radio and in newspapers [9]. "The fact is that the traditional media represent the main channel of communication, which directly influences the formation of opinions and attitudes of public opinion. However, rapid growth in the number of social network users, especially the younger population, has initiated the need to use communication potential of new media to communicate directly with selected target groups in order to inform them about the work, mission and tasks of an organization" [25].

The media is one of the mechanisms that enables the society and individuals to view themselves, the environment and the world. "With a lot of information, the public media paint our present on an invisible time screen every day. This media image of individual, but also wider, social reality is framed by the amount of information and the scope of our knowledge" [26]. However, the image that the media create does not have to completely coincide with reality. Sometimes that deviation is huge, to such an extent that the media image and reality differ in essence. "The staging of communication during the trans-mission of content is changing in the direction of a comprehensive picture of the society and consciousness. This builds social status, because the one who appears more often in the public represents relevance, competence, reliability and power" [27].

"The public trust in the Armed Forces, which in Serbia relies heavily on historical experience (the essential role of the military in establishing a sovereign state and maintaining national identity) and cultural traditions (high appreciation of struggle and war as a means of preserving freedom and independence) is subject to significant fluctuations if not supported by public knowledge about the sources of security risks, insight into the goals of the use of military force, the professional readiness of the military to perform the tasks defined by law and the practical results of its actions. It is largely formed on the attitude of the society that the Armed Forces, despite material-technical and orga- 
nizational-transitional problems, can perform their function of protection, especially in crisis or war situations. This is where, unfortunately, the knowledge (i.e. mental and preferential engagement) of the general public regarding the Armed Forces ends" [28].

Critical reconsideration of the foundations on which public opinion on the Armed Forces relies is a constant task of civil society since their good credibility in the eyes of the public is in the interest of both the state and society. It is in the nature of the media to quickly turn their attention from an event and topic to other. However, maintaining public attention to issues of public interest is a legitimate task of the media in the service of the public. It implies a professional decision to present a topic as a priority and to be constantly followed, as well as to develop public debate around it in order to find an optimal solution for the community. In a similar way-through planned professional engagement - the media should stimulate the interest of the civil sector in the optimal organization of the security and defence sector.

At general level, the goals of the media policy of the Serbian Armed Forces should be [28]:

- regular, timely and accurate informing of the public about all events and things that interest it;

- creating and maintaining a good opinion of the Serbian Armed Forces among national and target foreign public and profiling their image;

- use of all suitable ways of promotion and publicity for the purpose of constant communication with the society in order to provide stable social and state support;

- performing the abovementioned in cooperation with other state systems and elements, especially in the field of security, internal and foreign policy, and

- work of the competent services in the Serbian Armed Forces within the legally defined framework, with strict protection from daily political events and attempts at instrumentalization by any institution, party or individual.

Fulfilling the mentioned goals to a sufficient extent, as well as gaining adequate and constant media attention that have a positive attitude towards the Armed Forces, its purpose and role in the state and society, the Serbian Armed Forces can gain leverage of soft power and enable easier and more efficient functioning of the system, both in peacetime and wartime conditions.

\section{CONCLUSION}

The fact that the media are ubiquitous and pervasive has given the public new roles in the security sector. They have become a key link between the public (society) and the military. The way in which they interpret and thematize security threats (and in the case of Serbia also the military system reform) becomes crucial for public support to the Armed Forces (i.e. their reform).

Thus, the role of the media in redesigning a traditional dichotomy between the society and defence sector is one of the success factors in reforming the militarysecurity system. In that sense, maintaining a good image of the Serbian Armed Forces and their adequate media representation is not only in the interest of the security system, but also the Republic of Serbia. It is, therefore, an unavoidable function, but it has not been given adequate significance in the transformation of the military system (which is still ongoing).

"The Armed Forces, regardless of the fact that they are indisputably one of the state pillars, in the media space such as ours today cannot count on the support of most public media in advance. They have to fight for the support of public opinion, primarily by affirming the true values of the military 
organization and its social significance. This can be done only by professionals, capable of achieving goals of addressing the public and positively influencing the formation of desirable public opinion by an effective address in the media that are not a priori benevolent towards the Armed Forces-from the point of view of our Armed Forces in the process of their transformation into the armed force ready to respond to modern challenges" [29]. In addition to competent institutions and bodies, it is necessary to engage the professional public, especially the part that deals with research and analysis of the media and public opinion. When it comes to security factors, academics and mass media can play an important indirect role in defining and interpreting security issues [30].

In the absence of a clear media policy, the Serbian Armed Forces found themselves at a moment when the defence system is being reformed, as well. This enables the development of a strategy that can be coordinated with other elements of the defence and security system in the reform process. It can be concluded that it is necessary to establish a system of making and conducting media policy of the Armed Forces with the adoption of the highest defence documents, which have to contain properly defined and clearly set security, communication and general social goals, strategies and elements that support such media policy, which becomes an instrument of soft power by its adequate implementation.

In short, the Serbian Armed Forces must have a defined and adequate media policy that is continuously implemented in order to function better in peacetime, and to increase the chances of fulfilling defence and political goals in the event of crisis situations and war.

\section{Acknowledgment}

The paper was written within the project „Projection of trends of importance for the security of the Republic of Serbia until 2030", Strategic Research Institute, University of Defence in Belgrade.

\section{REFERENCES}

1. Vilkoks D, Kameron G, Olt F, Ejdži V. Odnosi s javnošću - strategije i taktike. Beograd: Ekonomski fakultetCentar za izdavačku delatnost. 2006. [Google Scholar]

2. Mek KD. Uvod u sociologiju masovnih komunikacija. Beograd: Glas. 1979. [Google Scholar]

3. Jevtović Z. Konferencija za štampu. CM - časopis za upravljanje komuniciranjem. 2007(4):135-151. [Google Scholar]

4. Glišić J. Demokratska civilna kontrola oružanih snaga - savremene teorijske rasprave. Beograd: BCBO. 2005. [Google Scholar]

5. Mitrović M. Mediji kao instrument strateške komunikacije u oružanim sukobima - Si-En-En efekat. Vojno delo. 2020;72(3):34-52. [Crossref] [SCIndeks] [PDF] [Google Scholar]

6. Mitrović M. Strateška komunikacija u funkciji nacionalne bezbednosti. Vojno delo. 2019;71(1):41-54. [Crossref] [SClndeks] [PDF] [Google Scholar]

7. Perić N. Medijska politika, informisanje javnosti, masovno komuniciranje i propaganda kao sredstva međunarodne politike i ideologije. Nacionalni interes - časopis za nacionalna i državna pitanja. 2008(3):169182. [Google Scholar]

8. Perić N. Kreiranje i evaluacija medijske politike na primeru Vojske Srbije. Beograd: Univerzitet Megatrend. 2008. [Google Scholar]

9. Barbulović S, Jevtović Z, Lakićević R, Popović M. Amnezija javnosti. Beograd: Grafo-Komerc. 2004. [Google Scholar]

10. Ranđelović S. Uvod u informisanje. Beograd: NIC Vojska. 2003. [Google Scholar]

11. Blagojević S, Zogović M, Pajović M. Politika odnosa sa javnošću u sistemu odbrane. Vojno delo. 2015;67(5):133145. [SCIndeks] [PDF] [Google Scholar]

12. Brigs A, Kolbi P. Uvod u studije medija. Beograd: CLIO. 2005. [Google Scholar]

13. Nacos B, Shapiro R, Isernia P. Decision-making in a Glass House: Mass Media, Public Opinion, and American Foreign Policy in the 21st Century. Boulder: Rowman \& Littlefield. 2000. [Google Scholar]

14. Bernays E. Propaganda. New York: Horace Liveright. 1928. [Google Scholar] 
15. Herman E. The Myth of the liberal Media. New York: Peter Lang Publishing Inc. 1999. [Google Scholar]

16. Bal F. Moć medija - mandarin i trgovac. Beograd: Clio. 1997. [Google Scholar]

17. Hartl J. The Importance of Public Opinion in Security and Defence Policy. In: Vlachová Marie, editor(s). Public Image of Security Defence and the Military in Europe. Geneva + Belgrade: DCAF-Geneva Centre + Center for Civil-Military Relations. 2003; p. 16-29. [Google Scholar]

18. Thorson K. Strategic Communication. Oxford Bibliographies [Internet]. 2013. Available from: https://www.oxfordbibliographies.com/view/document/obo-9780199756841/obo-9780199756841-0007.xml?rskey=nWAlBp\&result=221.

19. Jungblut M. Strategic Communication and its Role in Conflict News. Wiesbaden: Springer Fachmedien. 2019. [Google Scholar]

20. Vlachová M. The European Public Opinion On Security And Defence: A Good Message for Politicians and Soldiers. In: Vlachová Marie, editor(s). Public Image of Security Defence and the Military in Europe. Geneva + Belgrade: DCAF-Geneva Centre + Center for Civil-Military Relations. 2003; p. 284-293. [Google Scholar]

21. Holsti OR. Public Opinion and Foreign Policy: Challenges to the Almond-Lippman Consensus Mershon Series: Research Program and Debates. Int Stud Q. 1992;36(4):439-466. [Google Scholar]

22. Evert P, Pierangelo I. Public Opinion and the International Use of Force. London: Routledge. 2000. [Google Scholar]

23. Robinson P. The CNN effect: Can the news media drive foreign policy? Rev Int Stud. 1999;25(2):301-309. [Crossref] [Google Scholar]

24. Robinson P. Theorizing the Influence of Media on World Politics. Eur J Commun. 2001;16(4):523-544. [Crossref] [Google Scholar]

25. Šćekić R. The Media in the Service of Geopolitics. Media dialogues / Medijski dijalozi. 2015;8(3):33-39. [Google Scholar]

26. Eichenberg R. Victory Has Many Friends: U.S. Public Opinion and the Use of Military Force, 1981-2005. Int Secur. 2005;30(1):140-177. [Crossref] [Google Scholar]

27. Baran SJ, Davis DK. Mass Communication Theory: Foundations. Oxford: Oxford University Press. 2019. [Google Scholar]

28. Helmus TC, Paul C, Glenn RW. Enlisting Madison Avenue: The Marketing Approach to Earning Popular Support in Theaters of Operation. Santa Monica, CA: RAND Corporation. 2007. [Google Scholar]

29. Lippman W. Public Opinion. New York: Harcourt, Brace and Co. 1922. [Google Scholar]

30. Caspary WR. The 'Mood Theory': A Study of Public Opinion and Foreign Policy. Am Polit Sci Rev. 1970;64(2):536-547. [Crossref] [Google Scholar]

\title{
Nova medijska strategija Vojske Srbije kao instrument meke moći
}

\begin{abstract}
Sažetak:
Rad elaborira koncept i značaj medijske politike i primenjuje ga na Vojsku Srbije. Analizira se značaj medija u bezbednosnom sektoru na državnom i međunarodnom nivou i ističe potreba za dobrim medijskim predstavljanjem Vojske Srbije radi podrške javnosti za bitne odluke koje se tiču vojnih i bezbednosnih pitanja. Predstavljen je koncept strateških komunikacija i njihov odnos sa medijskom politkom koju bi Vojska morala da razvija kao jedan od instrumenata meke moći, što predstavlja interes ne samo ovog sistema već i države i društva. Takođe, navode se osnovni elementi čije ispunjavanje bi stvorilo uslove za kreiranje i vođenje adekvatne medijske politike kao instrumenta meke moći.
\end{abstract}

Ključne reči: Vojska Srbije; medijska politika; mediji; strateške komunikacije; javnost; javno mnjenje 